\title{
KEY DETERMINANTS OF THE QUALITY OF BUSINESS ENVIRONMENT OF SMES IN THE CZECH REPUBLIC
}

\author{
Zuzana Virglerová, Lubor Homolka, Luboš Smrčka, \\ Kornélia Lazányi, Tomáš Klieštik
}

\section{Introduction}

The business activity of small and midsize enterprises plays an important role in the individual economies of the European Union. In this regard, Cumming, Johan, and Zhang (2014) and Gawel (2010) indicate that entrepreneurship has a significantly positive impact on GDP/capita, exports/GDP, and patents per population, and a negative impact on unemployment.

SMEs are a key factor in maintaining and creating a functioning market economy, particularly as the means of stimulating competition, creating jobs, and promoting economic boost (Kessler, 2007).

According to the existing literature, increasing the competitive position of businesses, particularly small and mediumsized enterprises (SMEs), is an important driver for the development and renewal of national economies (Dúbravská et al., 2015; Virglerová et al., 2016; Belás \& Sopková, 2016; Adamowicz \& Machla, 2016; Belás et al., 2015; Kozubíková et al., 2015; West et al., 2008; Barbero et al., 2011; Wolf et al., 2012).

For SMEs, the environment in which they operate is another important factor. The environment has to be monitored, analysed, and new opportunities and threats need to be evaluated. Some studies point towards the necessity to analyze the business environment especially for newly established companies or for new CEOs. New CEOs have to gain knowledge about the organization and the environment in which the firm operates (Richard, Wu, \& Chadwick, 2009), are more likely to consider several alternatives, have a more external focus, and are more open to fresh ideas, change and experimentation than long inured CEOs (Hambrick, Geletkancyz, \& Fredrickson, 1993).

The aim of this article is to create a model of the quality of business environment, define the key determinants of this model, and quantify the correlations among the individual determinants in the area of small and medium-sized enterprises (SMEs) in the Czech Republic.

In the theoretical part, the segment of small and midsize enterprises is described, together with its benefits for the economy. Furthermore, business environment and its main determinants are defined, namely the state, society, financial markets and banks, and business risk. In the next section, there are presented the objectives, methodology and resources of information used in the present study. Finally, the most important recommendations for the theoretical area and the economic practice are stated.

\section{Theoretical Background}

In line with Henderson and Weiler (2010) who state that SMEs could be characterized as the most important catalyst for economic growth, the fact is that $99 \%$ of all companies are from the SME segment in the European Union and the USA (Bhaird, 2010). What is more, according to the SBA Fact Sheet SMEs form the backbone of the EU28 economy, by generating 3.9 trillion EUR value added in a year and employing 90 million people (European Union, 2016).

SMEs include the vast majority of private sector enterprises and ensure more than 50\% of employment and manage economic growth. On the other hand, due to their size, they often face both internal (lack of management skills) and external (unfavorable market conditions and institutional settings) obstacles that may hinder their further growth (Hessels \& Parker, 2013). 
SMEs are also quite important for the quality of life of the society. As Mathur (2011) states, SMEs play essential role in financing welfare of local communities as well as the cultural and sports life in the regions. The loss of an SME as a sponsor or patron due to its crisis makes a substantial effect on the existing social structures.

However, the state remains one of the most important determinants of the business environment, being the one who sets the rules for business and the one who supports or hinders the development in this area (Gavurova et al., 2016). One of the barriers for SMEs' survival and development seems to be the lack of institutional support, along with inadequate legislation and excessive regulations. Many SME managers complain about the bureaucratic processes that come along with these hindrances; furthermore, they find many services inadequate. Gallup Organization (2007) emphasizes that nearly half of SMEs in EU consider themselves as operating in an over-regulated environment and detect administrative regulations as the most important business constraint. What aggravates this situation is the scarce awareness, absence of information and time to take advantage of existing support. In addition, Ghobadian and Galler (1996) point out that SMEs are usually skeptical of outside help. According to Kuzmišin (2009), the improvement of business conditions, support of entrepreneurial spirit, flexible labour markets, company and worker adaptability, investments into education and science, research, and innovations, market access, and secure supply of energy - are permanent challenges for all players in the business environment.

SMEs, although being a significant economic force as a group are extremely vulnerable as single entities. To realize the extent of their susceptibility it has to be comprehended that the vast majority of SMEs (92.8\% of all ventures) are micro enterprises with less than 10 employees. They are usually underfinanced and are extremely susceptible to the surrounding social, legal and business environment (European Commission, 2016). According to the SBA Fact Sheet (European Union, 2016) the greatest weaknesses of SMEs are 'Skills \& innovation' and 'State \& public procurement', while the lack of sufficient entrepreneurship, the prevailing single market approach, and the still problematic access to finance are also major contributors when it comes to business failures (European Union, 2016).

The global financial and economic crisis worsened the conditions for SMEs business, which was reflected in the fact that the profitability of companies decreased, commercial banks tightened lending practices and that is why the access to debt finance worsened, too (Ključnikov \& Belás, 2016; Belás et al., 2014). Nonetheless, the negative trend seems to be breaking. 2014 was the first year since the recession, when SMEs were able to increase their employment (by 1.1\%) and the tendency was unbroken with an increase of $1.5 \%$ in 2015 . The same positive tendency is displayed by the increase in values added in 2014 and 2015, 3.8\% and 5.7\% respectively (Muller et al., 2016). Owing to these positive results according to the SAFE Survey results of 2016, after long years the SMEs regard not finding access as a comparatively less pressing problem (Van der Graaf et al., 2016).

SMEs which possess strong social ties with government officials are likely to gain access to unpublished market intelligence controlled by government agencies. Such intelligence can be leveraged to facilitate a firm's marketing capability (i.e. implementing key marketing activities) to achieve high level of customer satisfaction and trust (Luo et al., 2008). Kramoliš (2015) states that while the annual GDP growth fluctuates around zero, companies are likely to work hard to make a profit and try to cut costs while surviving on the market. Therefore all other activities (such as measuring the economic effects of design) are considered to be minor.

Aterido et al. (2009), Demirgüç-Kunt et al. (2006), Laeven and Woodruff (2007), and Love (2003) all indicate that firms face fewer obstacles in countries with better investment climates.

Better institutional environment can significantly improve SMEs' access to financing. It is not necessarily true that the entry of foreign banks will help domestic firms find access to credit. Therefore, governments in emerging markets may need to be more cautious when encouraging foreign investment in the banking industry. Greater institutional and economic development can substantially alleviate the difficulties SMEs face with respect to financing (Dong et al., 2014; Šoltés \& Gavurová, 2014). 
Regarding the setting of the business environment by the state, we must not omit the access of SMEs to sources of finance provided especially by banks. In this context Belás and Polách (2011) state that the banking system is influenced by many economic and noneconomic factors and banks have to apply strict standards to their risk management. This fact significantly determines the access of SMEs to bank loans.

Beck et al. (2006; 2008) suggest that small firms and firms in countries with poorly working institutions use less external sources of finance, especially from banks.

Bank loans are a key source of finance for SMEs (Howorth \& Moro, 2012) and informational opacity often hinders SMEs from obtaining such loans (Van Caneghem \& Van Campenhout, 2012; Ortiz-Molina \& Penas, 2008; HernándezCánovas \& Martínez-Solano, 2007).

SMEs, being more opaque and, therefore, more bound to their main bank, do not need as strong incentives as large firms to stay in the relationship. Banks, being aware of the difficulties encountered by SMEs in attracting new financial resources, will not be incentivized to offer them better credit terms (Sharpe, 1990). Consistent with this interpretation, Gopalan et al. (2007) found that the likelihood of not discontinuing (thus maintaining) a banking relationship is higher for very opaque firms confirming the idea of information rent being accumulated by the bank.

A number of papers find that SMEs are more financially constrained than large firms and, importantly, lack of access to external finance is a key obstacle to firm growth, especially for SMEs (Schiffer et al., 2001; Cressy, 2002; IADB, 2004). Amendola et al. (2014) found out that the risk of going bankrupt is higher for small firms, while the risk of being liquidated and inactive is lower for midsize firms. Moreover, young firms have a higher probability of going bankrupt or becoming inactive. On the contrary, old firms have a lower probability of being liquidated and becoming inactive.

New SMEs and those in their early stages are facing more financing problems from the banks than their more established counterparts. North et al. (2010) found out that young SMEs are twice as likely credit constrained than established firms and, more importantly, $17.1 \%$ of young firms did not receive any form of financing from the banks.
From an information asymmetry perspective, SMEs are generally viewed as riskier borrowers than larger companies (Berger \& Udell, 2005). Hanedar et al. (2013) found out that merely the size and location of the firm negatively affect the degree of collateral in banks. Larger firms located in larger cities seem to have the contractual power to mitigate the degree of collateral required. The location effect, on the other hand, is consistent for all firm sizes.

The study of Deakins et al. (2010) shows that SMEs were turned down to access funds from the banks due to poor presentation of the loan proposal by the SME owner, although the business was solvent and sound to be able to repay the loans. Lastly, the information gap between SMEs and banks can be reduced through good banking relationships and when the owner of the SME provides all necessary information to the bank managers. It increases the trust of the bank managers and it can help firms to access funds from the bank.

Studies have identified several types of information that are required when assessing SME loan applications (Deakins \& Hussain, 1994; Berry et al., 2004; Berry \& Robertson, 2006; Bruns \& Fletcher, 2008; Deakins et al., 2010; Rad et al., 2013). One important type of information is the collateral that signals the borrower's ability and commitment to repay the loan. Thus, a loan secured by collateral reduces the bank's credit risk (Berger \& Udell, 2006; Beck et al., 2009).

Wellalage and Stuart (2012), Sousa (2013) and Hauschildt et al. (2006) emphasize that the specifics of SMEs crisis also derives from the limited financial resources.

In order to reduce risks and potential crisis in business, the companies themselves should actively use risk management, they should identify business risks in time and eliminate them effectively.

Risk management is defined as the process intended to safeguard the assets of the company against losses that may hit it in the exercise of its activities, through the use of instruments of various kinds (prevention, retention, insurance, etc.) and in the best cost conditions (Urciuoli \& Crenca, 1989). Another definition is that RM refers to the process of planning, organizing, directing, and controlling resources to achieve given objectives when unexpected good or bad events are possible (Head, 2009).

All enterprises need to adopt a risk management (RM) strategy and methodology 
to identify, assess and treat risks (Verbano \& Venturini, 2013). SMEs need to practice RM much more than larger organisations because they suffer from resource limitations to respond promptly to both internal and external hazards which have the potential to cause enormous losses and even insolvency of the organization (Raghavan, 2005). However, in order to achieve a competitive edge and enhance the rate of success of their business, SMEs need to make risky decisions and engage in risky activities so that they can protect the innovativeness of delivering projects (Vargas-Hernández, 2011). Moreover, due to the prevalence of deregulations and market liberalization, SMEs encounter more uncertainties and challenges which make the SMEs' owners-managers consider RM as an integral part of the business management in order to keep the firms viable and productive (Yeo \& Lai, 2004). According to Taraba et al. (2015), it is also possible to transfer financial risk to suppliers by way of establishing contractual prices and introducing a penalization system in case that contract conditions are violated. If the risk occurs, it is possible (e.g. in terms of non-compliance) that the incurred costs will be refunded by the supplier.

The size of an organization influences the implementation and practice of risk management. The findings highlighted that the implementation of risk management within SMEs is influenced by two main integrated difficulties which are directly determined by the organizational characteristics. These difficulties include: scaling risk management, and tools and techniques adoption (Ward et al., 1991; Sparrow \& Bentley, 2000; Simu, 2006; Henschel, 2007).

\section{Objectives, Methodology and Resources}

The aim of this article is to create a model of the quality of business environment, define the key determinants of this model, and quantify the correlations among the individual determinants in the area of small and mediumsized enterprises (SMEs) in the Czech Republic. This aim was chosen because of scientific discussion about the most important determinant of business environment and their impact on small and medium enterprises in Czech Republic. These enterprises are not as resistant to the surroundings as bigger companies and the impact of the factors of business environment can be crucial for them. Therefore is very important to understand these factors for setting more suitable conditions for businesses in Czech Republic for increasing their competitiveness on the international market.

The aim was reached by questionnaire survey. In compliance with the results of this survey, the determinants which influence the quality of business environment in the Czech Republic were adjusted. Questionnaires were collected during the year 2015 via the on-line questionnaire. The research was carried out as follows. In total 1,650 companies had been chosen randomly from the Albertina database (only SMEs) and they were addressed directly by e-mail to complete the questionnaire in electronic form. If they did not complete the questionnaire, they were asked again to complete the questionnaire by phone. This process was repeated twice. Questionnaires were completed only by owners or managers of the companies. Finally, we received 1,171 responds. Although all the regions in the Czech Republic were covered, 323 companies were asked in the Zlín region. This bias is caused by the location of the university which carried out the research.

The majority of business owners were males $(75.4 \%)$. There were 740 micro $(<10$ employees), 306 small $(<50)$, and 95 medium $(<95)$ companies. Most of the companies (705) were established before 2005. 191 companies were founded between 2005 and 2010, and 245 companies are younger than 2005 .

According to the theoretical background, a model for the quality of business environment was created. Four variables were set (State, Public perception, Financial markets and banks, Business risks).

For describing the causal relations between the four variables, the Structural Equation Modelling (SEM) was used. This research deals with indirectly observable variables (latent constructs). The questionnaire was designed so as to capture the business owners' opinions by developing a set of questions covering the important dimension of underlying latent variable. Ten important dimensions related to the quality of business environment were postulated in the beginning of the research. Four questions (indicators) on the Likert scale of 5 levels were designed for each construct. In 
order to ensure that all factors are identifiable, Exploratory Factor Analysis (EFA) using minimal residuals estimation technique was selected. After the correlation matrix was found, Very Simple Structure (VSS) was employed to identify optimal number of factors. Maximal value of VSS complexity 1 was achieved with 5 factors, VSS with complexity 2 was virtually equal in the range of 3-10 factors. Bayesian information criterion suggests extracting 5 factors. These findings do not meet the initial expectations.

Compromise solution was used and EFA with 5 factors was made. Orthogonal rotation (varimax) technique was selected. During the iterative process, indicators with low communality, high cross-loadings $(>|0.4|)$ and small single-factor loadings $(>|0.2|)$ were removed. The most convenient solution which would meet the requirement of the face validity is presented in Tab. 2 . All factors were given a new name based on the composition indicators. The questions which were used in the correlation matrix are explained in Tab. 1.

\section{Results}

On the basis of a model created in compliance with our theoretical background, questions were defined and asked to SME owners in the Czech Republic. The questions were divided into four categories, as the following Fig. 1 indicates.

\section{Fig. 1: Original structural model with four variables}

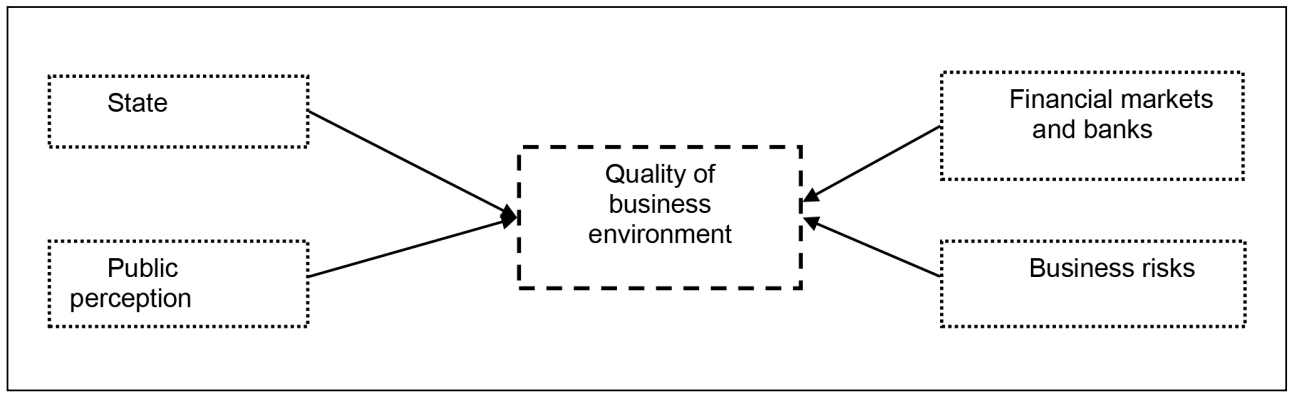

Source: own

The structural model in Fig. 1 presents the estimates of hypothesized relations (hypothesis). The perception of financial risk is affected by general environment $(\mathrm{H} 1)$, banks' approach to SMEs $(\mathrm{H} 2)$ and the business owners' knowledge $(\mathrm{H} 3)$. It is also expected that there is a covariance between the perception of the role of banks and the knowledge of banking rules and principles. Both factors are closely related to the banking sector. On the other hand, we do not assume large correlation of banking and state effects. In the structural model, we only assume one undirected relation between banking oriented factors (H5).

Selected categories of questions, answered by SME owners in the Czech Republic, were divided into groups in accordance with EFA and the following determinants of the business environment in the Czech Republic were constructed. We composed the correlation matrix from selected questions of questionnaire (Tab. 1).

By four-factor analysis, using the abovementioned indicators, no correlation matrix was identified (Fig. 2). The questions provided by the respondents did not correspond with these selected factors. Dividing the answers from the questionnaire into the four abovementioned groups was impossible. The selected factors which have an impact on the quality of business environment had to be changed according to the results and the relations between the provided answers.

Tab. 2 contains rotated factor loadings, abbreviated names of constructs which are used in the subsequent analysis, and reliability estimates. Construct reliability was estimated by Cronbach's alpha on 1,000 bootstrapped samples. 


\section{Ekonomika a management}

\section{Tab. 1: Questions which are used in the correlation matrix}

\begin{tabular}{l|l} 
stat1 & The state helps us in doing our business. \\
\hline kval2 & The state creates a favourable business environment for SMEs. \\
\hline stat4 & We consider the forms of financial support provided by the state to be adequately set. \\
\hline stat2 & I have a feeling that the state bullies us in our business. \\
\hline kval1 & I consider the business environment in the Czech Republic as favourable for starting a business. \\
\hline spol3 & Politicians and public realize that business owners are of benefit to society. \\
\hline kval3 & The conditions for business have improved over the last 5 years. \\
\hline trba3 & Banks apply too strict criteria for providing business loans. \\
\hline trba2 & Banks accept our needs and try to meet them. \\
\hline trba4 & SMEs have worse access to external sources of finance (financial markets, banks, government loans). \\
\hline firi3 & The importance of financial risk significantly increased during the crisis. \\
\hline pori2 & The intensity of business risks has increased dramatically after the crisis. \\
\hline uvri1 & The importance of credit risk increased during the crisis. \\
\hline uvri2 & The conditions for providing bank loans to SMEs are well known to business owners. \\
\hline uvri3 & The conditions for providing bank loans to SMEs are transparent. \\
\hline firi2 & The business owners are good managers of financial risks in their own firms. \\
\hline spol2 & When talking to other people, I feel appreciated for running a business. \\
\hline spol1 & I feel that my family and friends support my business activities. \\
\hline
\end{tabular}

Fig. 2: Factor loadings which are higher than $|0.1|$

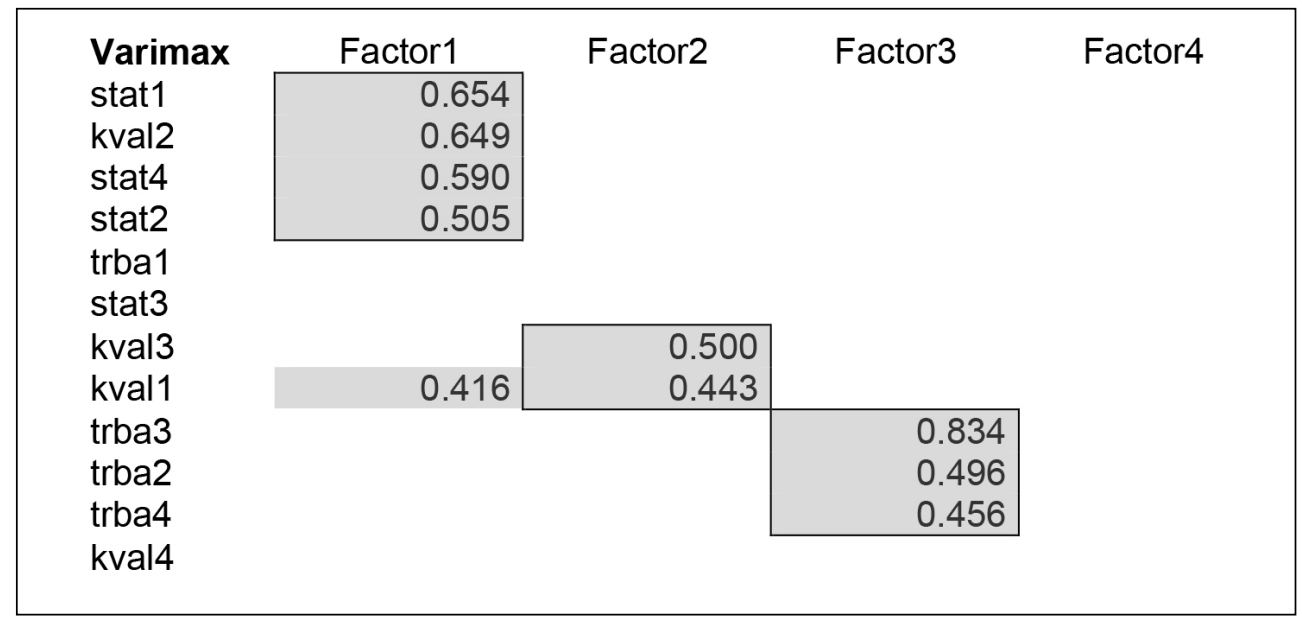




\begin{tabular}{|c|c|c|c|c|c|c|}
\hline & SP & BA & $\mathrm{FR}$ & $\mathrm{KP}$ & 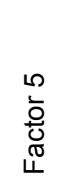 & 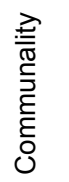 \\
\hline stat1 & 0.69 & & & 0.12 & & 0.51 \\
\hline kval2 & 0.67 & 0.11 & & 0.11 & & 0.52 \\
\hline stat4 & 0.56 & 0.15 & & & & 0.66 \\
\hline stat2 & 0.54 & 0.19 & 0.11 & & & 0.65 \\
\hline kval1 & 0.47 & & & 0.16 & 0.26 & 0.67 \\
\hline spol3 & 0.47 & & & 0.12 & 0.18 & 0.74 \\
\hline kval3 & 0.44 & & 0.10 & 0.16 & 0.23 & 0.72 \\
\hline trba3 & 0.10 & 0.73 & 0.16 & & & 0.43 \\
\hline trba2 & 0.18 & 0.55 & & 0.28 & 0.16 & 0.56 \\
\hline trba4 & 0.15 & 0.45 & 0.18 & & & 0.73 \\
\hline firi3 & & & 0.63 & & & 0.60 \\
\hline pori2 & 0.10 & & 0.60 & & & 0.62 \\
\hline uvri1 & & 0.13 & 0.56 & & & 0.66 \\
\hline uvri2 & 0.12 & & & 0.66 & & 0.54 \\
\hline uvri3 & 0.15 & 0.29 & & 0.46 & & 0.68 \\
\hline firi2 & & & & 0.40 & & 0.82 \\
\hline spol2 & & & & & 0.56 & 0.68 \\
\hline spol1 & 0.18 & & & & 0.48 & 0.74 \\
\hline $\begin{array}{l}\text { Cumulative } \\
\text { Variance }\end{array}$ & 0.13 & 0.20 & 0.26 & 0.32 & 0.36 & \\
\hline Reliability & 0.7677 & 0.6245 & 0.6256 & 0.5197 & 0.46 & \\
\hline
\end{tabular}

The questions making up the correlation matrix are defined in Tab. 2.

General State and Public Perception (SP) factor was identified as the most important one. This factor consists of 7 indicators. Moreover, it reached the highest reliability score, which might be inflated by the number of indicators compared to other constructs. Other constructs exhibit only weak reliability scores. These small values will affect path estimates in the SEM model. The strength of the directional path will be lowered in order to prevent achieving too optimistic results.
State and Public Perception (SP) contains questions related to both formal and informal support to business owners. Respondents who feel positive effects of government policies on their business as well as a positive perception from the wide public achieve high values of this construct. This factor is mostly composed of questions which contained either the word "state" or "politicians".

The second construct concerns Banks and their approach to business (BA). These questions aim to understand whether banks give enough support to companies in hard 


\section{Ekonomika a management}

times and whether SMEs experience increased difficulties during the credit approval process.

The third factor measures the importance of financial risks and their increase in post-crisis times (FR).

The fourth factor concerns knowledge of rules and principles (KP) which can help business owners in achieving a better position in negotiating with the banks over external finance. The literacy of business owners in the field of risk quantification and management is considered as well.
The last factor consists only of two indicators. Because of the low reliability and only two indicators, this factor will not be used in the subsequent analysis.

Finally, a five-factor solution was used. It explains $35.9 \%$ of all variance (from this factor SP explains 13\%, BA 7\%, FR 6\%, KP 6\% and factor 5 explains $4 \%$ - Tab. 2). Oblique factor rotation (oblimin) changes the values of loadings slightly.

The strongest influence on the perception of financial risks can be attributed to the

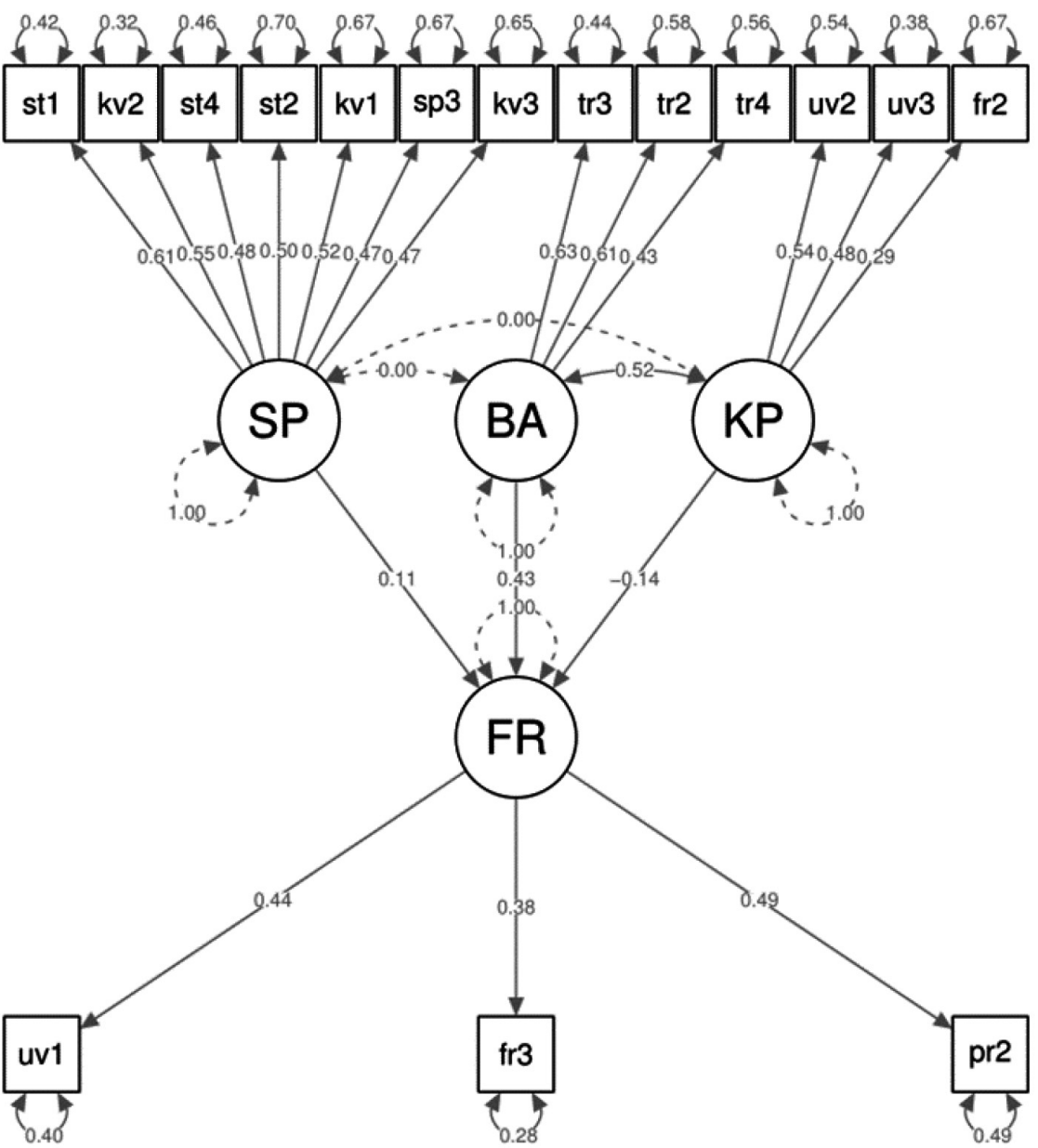


banking sector $(\mathrm{H} 2$, path coefficient $=0.43$, p-value < 0.01). Subjects who consider banks to have a positive effect tend to exhibit a more positive perception of risk (they claim that risks are not increasing and are manageable). The effect of KP was found negative $(\mathrm{H} 3$, path $=-0.142, p-v a l=0.05)$. This indicates that subjects with better knowledge of processes and rules perceive financial risks worse than others. The factor of general environment $(\mathrm{H} 1)$ has the same orientation as the banking sector effect, but it turned out that it is less important (path $=0.109, p$-value $=0.014)$. Lastly, the expectation of an existing correlation between banking-oriented factors ( $\mathrm{H} 5)$ was confirmed (0.524, p-value < 0.01).
Overall fit characteristics are summarized in Tab. 3. The value of Chi-square statistics suggests that the observed covariance matrix is different from the model covariance matrix. This can be, however, a result of a large sample size. Comparative Fit Index indicates only moderate fit quality. Absolute fit indicators RMSEA and SRMR reach satisfactory results given the sample size.

\section{Discussion}

The survey carried out confirmed a strong correlation between the factors "Banks and their approach to business" and "Knowledge of rules and principles". Business owners who know the principles of providing banking services and

Tab. 3: Summary of characteristics

\begin{tabular}{l|c} 
Chi-squared test & $538.605(\mathrm{df}=100, \mathrm{p}$-value $<0.01)$ \\
\hline Comparative Fit Index $(\mathrm{CFI})$ & 0.864 \\
\hline RMSEA & 0.062 \\
\hline SRMR & 0.091 \\
\hline
\end{tabular}

are good managers of financial risks perceive positively the attitude of banks and the way banking services are provided. A more difficult access of SMEs to external sources of finance was confirmed by $45 \%$ of respondents. The results of the survey can be understood as a confirmation of the statement by Shiffer et al. (2001), Cressy (2002), and IADB (2004) who found out that the lack of external sources of finance is the main obstacle to company growth.

A significant positive correlation was also confirmed between „Banks and their approach to business" and "Financial risks and their increase in post-crisis times". Business owners who have a positive perception of the banks' approach and of the access to external sources of finance are also more aware of the importance of risks and their increase during crisis and post-crisis time. More than $60 \%$ of respondents agree that the intensity of business risks has increased dramatically after the crisis. The increased importance of financial risk is even more intensely perceived during the crisis: more than $66 \%$ of business owners agree with this statement. Moreover, $61 \%$ of respondents also agree that the importance of credit risk increased in the time of crisis. The conclusion of this dependence may be the fact that if business owners perceive the influence of risks more intensely, they tend to apply risk management in their operations. Thereby they encourage a more forthcoming attitude of the banks, because as long as a system for reducing risks exists in such enterprises, they are less risky for the banks.

Contrariwise, a negative effect was found between the factors „Knowledge of rules and principles" and „Financial risks and their increase in post-crisis times". Business owners who think that they know the conditions for providing bank loans and who think that those conditions are transparent, do not perceive financial risks to have increased during and after the crisis. In other words, they do not perceive the importance of risks as intensely as the respondents who admit that they do not know the conditions for providing bank loans and who think the conditions are not transparent. The perception of risk can be therefore influenced by misunderstanding the conditions of a financial system in a given state. As soon as the entrepreneurs get a grasp of 
the conditions and rules governing the financial system, they can identify and manage risks more easily.

No relation was identified between the factor "State and public perception" and other defined factors. It was therefore not confirmed that a worse legislative environment or a worse performance of the politicians causes a stronger perception of risks or changes the banks' approach to financing businesses. The effect of the state on the knowledge of conditions for providing bank loans and the ability of entrepreneurs to manage financial risks was not confirmed either. Moreover, on the basis of this survey we cannot prove that the state's positive performance (either when setting the rules for starting a business or generally when creating a legislative framework for business) has a positive effect on the perception of risks by business owners or on their perception of the approach of banks as external sources of finance for SMEs. This survey did not confirm the previous surveys carried out by Dong et al. (2014) and Beck et al. (2006; 2008) who conclude that enterprises operating in an environment lacking sufficient state support have worse access to external sources of finance, especially from banks.

Beck et al. (2006; 2008) suggest that small firms and firms in countries with poor institutions use less external sources of finance, especially from banks.

\section{Conclusions}

The results of this survey have demonstrated that four groups of key determinants can be identified in the business environment studied among SMEs in the Czech Republic. The first and most global determinant is "State and public perception" which includes both the country's legislative background and the general public's perception of entrepreneurs. The second on is "Banks and their approach to business" which includes the most important external source of finance for SMEs in the Czech Republic. The third area is "Knowledge of rules and principles“ which determines the activities of business owners especially on the financial market. The last determinant is „Financial risks and their increase in post-crisis times" comprising the awareness of financial risks, risk management, and the changes in risk perception during the crisis and after it.
The strongest correlation confirmed by the survey is a positive influence of the perception of the banking environment and the perception of possible financial risks. Business owners who are aware of possible financial risks are more likely to identify them and adopt necessary measures to manage them. This activity is positively perceived by banks when deciding about providing loans to SMEs. This result also confirms the findings of Belás et al. (2014) who concluded that banks do offer helpful support to their SME clients, and that such support significantly reduces the financial problems faced by SMEs. This study also reveals that the support provided to SMEs from banks is considered valuable by many entrepreneurs. It implies that seeking assistance from banks may improve the ability of SMEs that face financial problems to survive.

Furthermore, negative effect of the knowledge of rules and principles on financial risk was identified. Business owners who have the necessary grasp of the financial market do not perceive financial risks as intensely as those lacking such knowledge.

The correlation between banks' approach and the knowledge of rules and principles of the financial market was confirmed, too. The participating business owners who responded positively to questions concerning the knowledge of the financial market also exhibited positive perception of the banks' approach to providing external finance. On the other hand, entrepreneurs who perceive the banks' approach negatively lack the necessary knowledge of the financial market. This may confirm the conclusions of the survey carried out by Deakins et al. (2010) which shows that many SMEs were turned down by banks to access finance due to poorly presented or erroneous Ioan application. Negative perception of banks as important providers of external finance may thus be caused by the fact that business owners have unrealistic expectations resulting from misunderstanding the country's financial system.

This study struggles with several limitations. Firstly, the survey is geographically limited to SMEs from the Czech Republic only. Another possible limitation may stem from misunderstanding the questions by the respondents or their providing untruthful answers. Because of these limitations, the results of the survey cannot be generalized. 
This paper was supported by Project $R O$ FaME/2016: The business environment of small and medium enterprises.

\section{References}

Adamowicz, M., \& Machla, A. (2016). Small and Medium Enterprises and the Support Policy of Local Government. Oeconomia Copernicana, 7(3), 405-437. doi:10.12775/OeC.2016.024.

Amendola, A., Restaino, M., \& Sensini, L. (2015). An analysis of the determinants of financial distress in Italy: a competing risks approach. International Review of Economics and Finance, 37(1), 33-41. doi:10.1016/j.iref.2014.10.012.

Aterido, R., Hallward-Driemeier, M., \& Pages, C. (2009). Big Constraints to Small Firms' Growth Business Environment and Employment Growth Across Firms [Policy Research Working Paper no. 5032]. Washington, DC: World Bank.

Barbero, J. L., Casillas, J. C., \& Feldman, H. D. (2011). Managerial capabilities and paths to growth as determinants of high-growth small and medium-sized enterprises. International Small Business Journal, 29(6), 671-694. doi:10.1177/0266242610378287.

Beck, T., Demirgüç-Kunt, A., \& Maksimovic, V. (2008). Financing Patterns Around the World: Are Small Firms Different? Journal of Financial Economics, 89(3), 467-487. doi:10.1016/j. jineco.2007.10.005.

Beck, T., Demirgüç-Kunt, A., Laeven, L., \& Maksimovic, V. (2006). The Determinants of Financing Obstacles. Journal of International Money and Finance, 25(6), 932-952. doi:10.1016/j.jimonfin.2006.07.005.

Beck, T., Behr, P., \& Guttler, A. (2009). Gender and banking: are women better loan officers? [Working Paper Series No. 2009-19]. London: European Banking Center Discussion: Centre for Economic Policy Research.

Belás, J., \& Sopková, G. (2016). Significant determinants of the competitive environment for SMEs in the context of financial and credit risks. Journal of International Studies, 9(2), 139-149. doi:10.14254/2071-8330.2016/9-2/10.

Belás, J., Demjan, V., Habánik, J., Hudáková, M., \& Sipko, J. (2015). The business environment of Small and mediumsized companies in selected regions of the Czech Republic and Slovakia. E\&M Ekonomie a Management, 18(1), 95-110. doi:10.15240/ tul/001/2015-1-008.
Belás, J., Bartoš, P., Habánik, J., \& Novák, P. (2014). Significant attributes of the business environment in small and medium-sized enterprises. Economics \& Sociology, 7(3), 2239. doi:10.14254/2071-789X.2014/7-3/2.

Belás, J., \& Polách, J. (2011). Economic Imbalance and Regulatory Traps in Banking Sector. In Proceedings of the 5th International Scientific Conference Finance and the performance of firms in science, education and practice (pp. 28-36). Zlín.

Berger, A. N., \& Udell, G. F. (2005). Small business and debt finance. In Z. J. Acs, \& D. B. Audrets (Eds.), Handbook of Entrepreneurship Research (pp. 299-328). New York, NY: Springer.

Berger, A. N., \& Udell, G. F. (2006). A more complete conceptual framework for SME finance. Journal of Banking \& Finance, 30(11), 2945-2966. doi:10.1016/j.jbankfin.2006.05.008.

Berry, A., Grant, P., \& Jarvis, R. (2004). European bank lending to the UK SME sector: an investigation of approaches adopted. International Small Business Journal, 22(2), 115-130. doi:10.1177/0266242604041310.

Berry, A., \& Robertson, J. (2006). Overseas bankers in the UK and their use of information for making lending decisions. The British Accounting Review, 38(2), 175-191. doi:10.1016/j.bar.2005.10.004.

Bhaird, C. M. (2010). Resourcing Small and Medium Sized Enterprises. Berlin: Springer Verlag.

Bruns, V., \& Fletcher, M. (2008). Banks' risk assessment of Swedish SMEs. Venture Capital, 10(2), 171-194. doi:10.1080/13691060801946089.

Cumming, D., Johan, S., \& Zhang, M. (2014). The economic Impact of Entrepreneurship: Comparing International Datasets. Corporate Governance: An International Review, 22(2), 162-178. doi:10.1111/corg.12058.

Cressy, R. (2002). Funding gaps: A symposium. Economic Journal, 112(477), 1-16. doi:10.1111/1468-0297.00680.

Deakins, D., \& Hussain, G. (1994). Risk assessment with asymmetric information. The International Journal of Bank Marketing, 12(1), 24-31. doi:10.1108/02652329410049571.

Deakins, D., Whittam, G., \& Wyper, J. (2010). SMEs' access to bank finance in Scotland: an analysis of bank manager decision making. Venture Capital, 12(3), 193-209. doi:10.1080/13691061003658647.

Demirgüç-Kunt, A., Love, I., \& Maksimovic, V. (2006). Business Environment and the Incorporation Decision. Journal of Banking \& 
Finance, 30(11), 2967-2993. doi:10.1016/j. jbankfin.2006.05.007.

Dong, Y., \& Men, C. (2014). SME financing in emerging markets: Firm characteristics, banking structure and institutions. Emerging Markets Finance and Trade, 50(1), 120-149. doi:10.2753/REE1540-496X500107.

Dúbravská, M., Mura, L., Kotulič, R., \& Novotný, J. (2015). Internationalization of Entrepreneurship - Motivating Factors: Case Study of the Slovak Republic. Acta Polytechnica Hungarica, 12(5), 121-133.

European Commission. (2016). SME Performance Review 2015/2016. Retrieved Febraury 01, 2017, from http://ec.europa.eu/ growth/smes/business-friendly-environment/ performance-review-2016_en\#annual-report.

European Union. (2016). SBA Fact Sheet. Brussels: European Commission DirectorateGeneral for Internal Market, Industry, Entrepreneurship and SMEs.

Gallup Organization. (2007). Observatory of European SMEs, No 196. Brussels: European Commission.

Gavurova, B., Vagasova, T., \& Kovac, V. (2016). Competitiveness Assessment of Slovak Republic Regions. In J. Krajicek, J. Nesleha, \& K. Urbanovsky (Eds.), European Financial System 2016. 13th International Scientific Conference of the European Financial Systems (pp. 175-186). Brno.

Gawel, A. (2010). The Relationship between Entrepreneurship and Unemployment in the Business Cycle. Journal of International Studies, 3(1), 59-69. doi:10.14254/2071-8330.2010/3-1/7.

Ghobadian, A., \& Galler, D. N. (1996). Total quality management in SMEs. International Journal of Management Science, 16(1), 83-106. doi:10.1016/0305-0483(95)00055-0.

Gopalan, R., Nanda, V. K., \& Seru, A. (2007). Affiliated firms and financial support: evidence from indian business groups. Journal of Financial Economics, 86(3), 759-795. doi:10.1016/j.jfineco.2006.09.008.

Hambrick, D. C., Geletkancyz, M., \& Fredrickson, J. W. (1993). Top executive commitment to the status quo: Some tests of its determinants. Strategic Management Journal, 14(6), 401-418. doi:10.1002/smj.4250140602.

Hanedar, E. Y., Broccardo, E., \& Bazzana, F. (2013). Collateral requirements of SMEs: The evidence from less-developed countries. Journal of Banking \& Finance, 38(January), 106-121. doi:10.1016/j.jbankfin.2013.09.019.
Hauschildt, J., Grape, C., \& Schindler, M. (2006). Typologien von Unternehmenskrisen im Wandel. Die Betriebswirtschaft, 66(1), 7-25.

Head, L. G. (2009). Risk Management Why and How. Dallas, TX: International Risk Management Institute.

Henderson, J., \& Weiler, S. (2010). Entrepreneurs and job growth: probing the boundaries of time and space. Economic Development Quarterly, 24(1), 23-32. doi:10.1177/0891242409350917.

Henschel, T. (2007). Risk Management Practices in the Main Industries of German Small to Medium-Sized Enterprises, An Empirical Investigation (Doctoral dissertation). Napier University, Edinburgh.

Hernández-Cánovas, G., \& MartínezSolano, P. (2007). Effect of the number of banking relationships on credit availability: Evidence from panel data of Spanish small firms. Small Business Economics, 28(1), 37-53. doi:10.1007/s11187-005-6704-z.

Hessels, J., \& Parker, S. C. (2013). Constraints, internationalization and growth: A cross-country analysis of European SMEs. Journal of World Business, 48(1), 137-148. doi:10.1016/j.jwb.2012.06.014.

Howorth, C., \& Moro, A. (2012). Trustworthiness and interest rates: An empirical study on Italian SMEs. Small Business Economics, 39(1), 161-177. doi:10.1007/s11187-010-9285-4.

IADB. (2004). Unlocking Credit: The Quest for Deep and Stable Lending. Washington, DC: Inter-American Development Bank and Johns Hopkins University Press.

Kessler, A. (2007). Success factors for new businesses in Austria and the Czech Republic. Entrepreneurship and Regional Development, 19(1), 381-403. doi:10.1080/08985620701439959.

Ključnikov, A., \& Belás, J. (2016). Approaches of Czech Entrepreneurs to Debt Financing and Management of Credit Risk. Equilibrium. Quarterly Journal of Economics and Economic Policy, 11(2), 343-365. doi:10.12775/ EQUIL.2016.01.

Kozubíková, L., Belás, J., Ključnikov, A., \& Virglerová, Z. (2015). Differences in approach to selected constructs of entrepreneurail orientation in SME segment regarding the selected sociodemographic factors. Transformation in Business and Economics, 14(3C(36C)), 333-355.

Kramoliš, J. (2015). Design as a Condition for Prosperity in Czech Businesses - A Comparative 
Study. Journal of Competitiveness, 7(4), 33-47. doi:10.7441/joc.2015.04.03.

Kuzmišin, P. (2009). The Quality of Business Environment and its Effect on the Competitiveness of a Business. Journal of Competitiveness, 1(1), 42-55.

Laeven, L., \& Woodruff, C. (2007). The Quality of the Legal System, Firm Ownership, and Firm Size. Review of Economics and Statistics, 89(4), 601-614. doi:10.1162/rest.89.4.601.

Love, I. (2003). Financial Development and Financing Constraints: International Evidence from the Structural Investment Model. Review of Financial Studies, 16(3), 765-791. doi:10.1093/ rfs/hhg013.

Luo, X., Hsu, M. K. \& Liu, S. S. (2008). The moderating role of institutional networking in the customer orientation-trust/ commitmentperformance causal chain in China. Journal of the Academy of Marketing Science, 36(2), 202-214. doi:10.1007/s11747-007-0047-z.

Mathur, A. (2011). Beyond Bankruptcy: Does the Bankruptcy Code Provide a Fresh Start To Entrepreneurs? [Working Paper, April]. USA: Office of Advocacy.

Muller, P. et al. (2016). Annual Report on European SMEs 2015 / 2016 - SME recovery continues [Contract number: EASME/ COSME/2015/012]. European Union.

North, D., Baldock, R., \& Ekanem, I. (2010). Is there a debt finance gap relating to Scottish SMEs? A demand side perspective. Venture Capital, 12(3), 173-192. doi:10.1080/13691061003658670.

Ortiz-Molina, H., \& Penas, M. F. (2008). Lending to small businesses: The role of loan maturity in addressing information problems. Small Business Economics, 30(4), 361-383. doi:10.1007/s11187-007-9053-2.

Rad, A., Wahlberg, O., \& Ohman, P. (2013). How lending officers construe assessments of small and medium-sized enterprise loan applications: a repertory grid study. Journal of Constructivist Psychology, 26(4), 262-279. doi:10.1080/10720537.2013.812856.

Raghavan, R. S. (2005). Chartered Accountant Report. Retrieved January 29, 2014, from http://220.227.161.86/10412528-535.pdf.

Richard, O. C., Wu, P., \& Chadwick, K. (2009). The impact of entrepreneurial orientation on firm performance. The role of CEO position tenure and industry tenure. The International Journal of Human Resource Management, 20(5), 10781095. doi:10.1080/09585190902850281.
Sharpe, S. A. (1990). Asymmetric information, bank lending and implicit contracts: a stylized model of customer relationships. Journal of Finance, 45(1), 1069-1087. doi:10.1111/j.1540-6261.1990.tb02427.x.

Schiffer, M., \& Weder, B. (2001). Firm size and the business environment: Worldwide survey results [International Finance Corporation Discussion Paper 43]. Retrieved from http://documents.worldbank.org/curated/ en/574601468739143195/pdf/multiOpage.pdf.

Simu, K. (2006). Risk Management in Small Construction Projects (Licentiate thesis). Department of Civil and Environmental Engineering, Luleå tekniska universitet, Luleå./ Luleå University of Technology.

Sousa, M. D. (2013). Just punch my bankruptcy ticket: a qualitative study of mandatory debtor financial education. Marquette Law Review, 97(2), 391-467.

Sparrow, J., \& Bentley, P. (2000). Decision tendencies of entrepreneurs and small business risk management practices. Risk Management, An International Journal, 2(1), 17-26.

Šoltés, V., \& Gavurová, B. (2014). Innovation policy as the main accelerator of increasing the competitiveness of small and medium-sized enterprises in Slovakia. In Procedia Economics and Finance: Emerging Markets Queries in Finance and Business: 24-27 October 2013 (pp. 1478-1485). Tîrgu Mureş, Romania: Elsevier.

Taraba, P., Heinzová, R., Pitrová, K., Hart, M., \& Trojan, J. (2015). Project risks in enterprises in the Czech Republic. In Proceedings of the 25th International Business Information Management Association Conference - Innovation Vision 2020: From Regional Development Sustainability to Global Economic Growth (pp. 814-821). IBIMA.

Urciuoli, V., \& Crenca, G. (1989). Risk Management: strategie e processi decisionali nella gestione dei rischi puri d'impresa. Rovereto: ISBA.

Van Caneghem, T., \& Van Campenhout, G. (2012). Quantity and quality of information and SME financial structure. Small Business Economics, 39(2), 341-358. doi:10.1007/s11187-010-9306-3.

Van der Graaf, A., Kwaak, T., \& Van der Zeijden, P. (2016). Survey on the access to finance of enterprises (SAFE). Brusseles: EUROPEAN COMMISSION DirectorateGeneral for Internal Market, Industry, Entrepreneurship and SMEs. 


\section{Ekonomika a management}

Vargas-Hernandez, J. G. (2011). Modelling risk and innovation management. Advances in Competitiveness Research, 19(3-4), 45-57.

Verbano, C., \& Venturini, K. (2013). Managing risks in SMEs: a literature review and research agenda. Journal of Technology Management \& Innovation, 8(3), 186-197.

Virglerova, Z., Dobes, K., \& Vojtovic, S. (2016). The Perception of the State's Influence on its Business Environment in the SMEs from Czech Republic. Administratie si Management Public, 26.

Ward, S. C., Chapman, C. B., \& Curtis, B. (1991). On the allocation of risk in construction projects. International Journal of Project Management, 9(3), 140-147. doi:10.1016/02637863(91)90038-W.

Wellalage, H. N., \& Stuart, L. (2012). Factors Affecting the Probability of SME Bankruptcy: A Case Study on New Zealand Unlisted Firms. Business Journal for Entrepreneurs, (June), 1-17.

West, G. P. et al. (2008). Contrasting entrepreneurial economic development in emerging Latin American economies: Applications and extensions of resourcebased theory. Entrepreneurship Theory and Practice, 32(1), 15-36. doi:10.1111/j.15406520.2007.00214.x.

Wolf, P, Kaudela-Baum, S., \& Meissner, J. O. (2012). Exploring innovating cultures in small and medium-sized enterprises: Findings from Central Switzerland. International Small Business Journal, 30(3), 242-274. doi:10.1177/0266242610386666.
Yeo, K. T., \& Lai, W. C. (2004). Risk management strategies for SME investing in China: a Singaporean perspective. IEEE International Engineering Management Conference Proceedings, 2(1), 794-798.

Ing. Zuzana Virglerová, Ph.D. Tomas Bata University in Zlín Faculty of Management and Economics Centre for Applied Economic Research virglerova@fame.utb.cz

Ing. Lubor Homolka, Ph.D. Tomas Bata University in Zlín

Faculty of Management and Economics Department of Statistics and Quantitative Methods homolka@fame.utb.cz

Assoc. Prof. Ing. Luboš Smrčka, CSc. University of Economics Prague Faculty of Business Administration

Department of Strategy smrckal@vse.cz

Kornélia Lazányi, Ph.D. habil. Óbuda University

Faculty of Business and Management Institute of Management and Organisation lazanyi.kornelia@kgk.uni-obuda.hu

prof. Ing. Tomáš Klieštik, PhD. University of Žilina Faculty of Operation and Economics of Transport and Communications tomas.kliestik@pedas.uniza.sk 


\section{Abstract}

\section{KEY DETERMINANTS OF THE QUALITY OF BUSINESS ENVIRONMENT OF SMES IN THE CZECH REPUBLIC}

\section{Zuzana Virglerová, Lubor Homolka, Luboš Smrčka, Kornélia Lazányi, Tomáš Klieštik}

The business environment is determined by various obstacles the business owners have to deal with in the course of their work. This article aims to create a model of the quality of business environment, define the key determinants of this model, and quantify the correlations among the individual determinants in the area of small and medium-sized enterprises (SMEs) in the Czech Republic. Partial results of a survey carried out at the Tomas Bata University in Zlin in 2015 were used for the analysis. On the basis of previous surveys, four determinants were set that influence the quality of business environment (State, Public perception, Financial markets and banks, Business risks). From these four areas, questions were selected and asked to business owners in the Czech Republic in the abovementioned survey. Links were identified among selected questions asked to the owners. These links led to adjusting the business environment to four determinants: State and public perception, Banks and their approach to business, Knowledge of rules and principles, and financial risks and their increase in post-crisis time. Subsequently, correlations were identified among these determinants. It was ascertained that the knowledge of the conditions of the financial system leads to a positive perception of the banks' approach in terms of external finance. Moreover, a positive influence of the banking sector on how the business owners perceive financial risks was identified. Another important result of the survey is the fact that business owners who have the necessary knowledge of the financial market perceive financial risks as less intense compared to those lacking such knowledge of the financial market.

Key Words: Business environment, SMEs, risk management, quality of business environment of SMEs.

JEL Classification: G32, L26, M12.

DOI: 10.15240/tul/001/2017-2-007 